\title{
Molecular diagnosis of autosomal dominant early onset Alzheimer's disease: an update
}

\author{
G Raux, L Guyant-Maréchal, C Martin, J Bou, C Penet, A Brice, D Hannequin, T Frebourg, \\ D Campion
}

Background: Autosomal dominant early onset Alzheimer's disease (ADEOAD) is genetically heterogeneous. Mutations of the amyloid precursor protein (APP), presenilin 1 (PSEN1), and presenilin 2 (PSEN2) genes have been identified.

Objective: To further clarify the respective contribution of these genes to ADEOAD.

Methods: 31 novel families were investigated. They were ascertained using stringent criteria (the occurrence of probable or definite cases of Alzheimer's disease with onset before 60 years of age in three generations). All cases fulfilled the NINCDS-ADRDA criteria for probable or definite Alzheimer's disease. The entire coding regions of PSEN1 and PSEN2 genes and exons 16 and 17 of APP gene were sequenced from genomic DNA

Results: PSEN1 mutations, including eight previously unreported mutations, were detected in 24 of the 31 families, and APP mutations were found in five families. In this sample, the mean ages of disease onset in PSEN1 and APP mutation carriers were 41.7 and 51.2 years, respectively.

Conclusions: Combining these data with previously published data, yielding 65 ADEOAD families, $66 \%$ of the cases were attributable to PSEN1 mutations and $16 \%$ to APP mutations, while $18 \%$ remained unexplained.

$\mathrm{T}$ en years after the discovery of the presenilin 1 (PSENI) gene, ${ }^{1}$ which is involved in autosomal dominant early onset Alzheimer's disease (ADEOAD), there is an increasing requirement for presymptomatic testing in affected families. ADEOAD is genetically heterogeneous and mutations of the amyloid precursor protein (APP) and presenilin 2 (PSEN2) have also been identified in ADEOAD patients. However, there is no consensus about the relative contribution of PSENI mutations to ADEOAD. Accurate determination of the relative contribution of PSEN1, PSEN2, and APP mutations to ADEOAD is important to ensure efficient genetic counselling in affected families.

In a previous report, mutational analysis of these three genes in 34 ADEOAD families led us to conclude that $71 \%$ of cases in these families were attributable to mutations within the PSENI and APP genes. ${ }^{2}$ However, other groups have recently reported lower estimates on smaller samples. ${ }^{3-5}$ To further clarify the respective contribution of these genes to ADEOAD, we analysed 31 novel families ascertained using the stringent criteria we have previously defined (that is, the occurrence of probable or definite Alzheimer's disease cases with onset before 60 years of age in three generations). ${ }^{2}$ All cases fulfilled the NINCDS-ADRDA criteria for probable or definite Alzheimer's disease. Clinical and molecular investigations were carried out after informed consent of participating family members was obtained.
The entire coding regions of PSEN1 and PSEN2 were sequenced, either from reverse transcriptase polymerase chain reaction (RT-PCR), undertaken on mRNA extracted from lymphoblastoid cell lines as previously described, ${ }^{6}$ or from genomic DNA, and exons 16 and 17 of APP were sequenced from genomic DNA. ${ }^{1} A P O E$ genotypes were also determined. The results are summarised in table 1. PSENI mutations, including eight previously unreported mutations, were detected in 24 of the 31 families, and APP mutations were found in five. In this sample, the mean ages of Alzheimer's disease onset in PSENI and APP mutation carriers were 41.7 and 51.2 years, respectively. We detected no PSEN2 mutations in the two remaining families without mutation within PSENI or APP. In these families without detectable mutations within PSEN1, PSEN2, or APP exons 16 and 17 , we completed the analysis by sequencing exons $1-15$ of APP and exons 1-5, 7, and 9-14 of MAPT (microtubule associated protein tau) from genomic DNA, as the clinical presentation of Alzheimer's disease and frontotemporal dementia with parkinsonism linked to chromosome 17 (FTDP-17) may overlap. This complementary analysis revealed no additional mutations.

Among the eight novel PSENI mutations, four affected residues that had already been shown to be mutated in ADEOAD patients. The four other novel PSENI mutations concerned residues that are conserved between PSEN1 and PSEN2 genes and which are also conserved in evolution. For two of these eight novel PSENI mutations, cosegregation with the disease could clearly be demonstrated in two families with multiple affected living members. Three PSEN1 mutations (P264L, E280G, and F386S) were associated with an atypical presentation including spastic paraparesis. We had previously reported the occurrence of the P264L mutation in another family with spastic paraparesis, ${ }^{7}$ but the novel F386S mutation appears to be also associated with this phenotype. The E318G variation, which had been described either as a non-pathogenic polymorphism $^{89}$ or as a mutation with reduced penetrance, ${ }^{10}{ }^{11}$ was present in three families. In these three families, DNA was only available from the proband, thus precluding any cosegregation analysis. In family ALZ-231, in which the Q120N mutation cosegregates with the disease, one patient also bore the R35G substitution already described by Rogaeva et al. ${ }^{12}$ Absence of cosegregation of the R35G substitution with the disease within this family shows that this substitution is a non-causative rare variant. Finally, $78 \%$ of the affected subjects had an APOE 3-3 genotype and none had the APOE 4-4 genotype.

Abbreviations: $A D E O A D$, autosomal dominant early onset Alzheimer's disease; NINCDS-ADRDA, National Institute of Neurological and Communicative Diseases and Stroke/Alzheimer's Disease and Related Disorders Association 
Table 1 Detection of PSEN1 and APP mutations among 29 families with autosomal dominant early onset Alzheimer's disease

\begin{tabular}{|c|c|c|c|c|}
\hline Family & AOO (years) & $\begin{array}{l}\text { Affected } \\
\text { subjects (n) }\end{array}$ & $A P P$ & PSEN1 \\
\hline ALZ 184 & 53 to 58 & 3 & WT & c. $315 \mathrm{~T} \rightarrow \mathrm{A} ; \mathrm{F} 105 \mathrm{I}^{\star}$ \\
\hline ALZ 157 & 30 to 33 & 4 & WT & c. $347 \mathrm{C} \rightarrow \mathrm{A} ; \mathrm{T} 116 \mathrm{~N}$ \\
\hline ANG 008 & 40 to 47 & 4 & WT & c. $347 \mathrm{C} \rightarrow \mathrm{T} ; \mathrm{T} 116 \mathrm{I}^{*}$ \\
\hline ALZ 231 & 43 to 48 & 4 & WT & c. $360 \mathrm{~A} \rightarrow \mathrm{C} ; \mathrm{Q} 120 \mathrm{~N} \dagger$ \\
\hline ROU 001 & 34 to 35 & 3 & WT & c. $428 \mathrm{~T} \rightarrow \mathrm{C} ; 1143 \mathrm{~W}$ \\
\hline ALZ 175 & 45 to 50 & 5 & WT & c. $428 \mathrm{~T} \rightarrow \mathrm{A} ; 1143 \mathrm{~N}^{*}$ \\
\hline ALZ 148 & 34 to 40 & 5 & WT & c. $459 \mathrm{C} \rightarrow \mathrm{G} ; \mathrm{L} 153 \mathrm{~V} \dagger$ \\
\hline ALZ 180 & 39 to 44 & 4 & WT & c. $459 \mathrm{C} \rightarrow \mathrm{G} \mathrm{L153V \dagger}$ \\
\hline ALZ 156 & 36 to 42 & 4 & WT & c.529T $\rightarrow$ C; F177L $†$ \\
\hline ALZ 219 & 32 to 34 & 5 & WT & c. $617 \mathrm{G} \rightarrow \mathrm{A} ; \mathrm{G} 206 \mathrm{~N} \dagger$ \\
\hline KRI 001 & 30 to 35 & 15 & WT & c. $616 \mathrm{G} \rightarrow \mathrm{A} ; \mathrm{G} 206 \mathrm{~S} \dagger^{*}$ \\
\hline ALZ 178 & 37 to 45 & 5 & WT & c. $640 \mathrm{C} \rightarrow \mathrm{T} ; \mathrm{H} 214 \mathrm{Y} \ddagger$ \\
\hline ALZ 163 & 37 to 46 & 5 & WT & $\mathrm{c.} 698 \mathrm{~T} \rightarrow \mathrm{C}^{\prime} \mathrm{M}^{2} 33 \mathrm{~T}^{+}$ \\
\hline ALZ. 202 & 38 to 40 & 3 & WT & c.698T $\rightarrow C ; M 233 \mathrm{~T}$ \\
\hline ALZ 183 & 47 to 51 & 4 & WT & c.791C $\rightarrow$ T; P264L† \\
\hline ALZ 150 & 43 to 47 & 4 & WT & c. $839 \mathrm{~A} \rightarrow \mathrm{G} ; \mathrm{E} 280 \mathrm{G}$ \\
\hline ALZ 179 & 52 to 58 & 3 & WT & c. $953 \mathrm{~A} \rightarrow \mathrm{G} ; \mathrm{E} 318 \mathrm{G}$ \\
\hline LEF 063 & 45 to 51 & 3 & WT & c. $953 \mathrm{~A} \rightarrow \mathrm{G} ; \mathrm{E} 318 \mathrm{G}$ \\
\hline KER 061 & 49 to 59 & 3 & WT & c. $953 \mathrm{~A} \rightarrow \mathrm{G} ; \mathrm{E} 318 \mathrm{G}$ \\
\hline POI 060 & 37 to 58 & 5 & WT & c. $1157 \mathrm{~T} \rightarrow C ;$ F386S†‡ \\
\hline ALZ 174 & 42 to 45 & 3 & WT & c. $1171 \mathrm{G} \rightarrow \mathrm{T} ; \mathrm{V} 391 \mathrm{Ff}$ \\
\hline ALZ 154 & 39 to 47 & 5 & WT & c. $1174 \mathrm{C} \rightarrow \mathrm{G} ; \mathrm{L} 392 \mathrm{~V} \dagger$ \\
\hline ALZ 147 & 41 to 48 & 6 & WT & c. $1174 \mathrm{C} \rightarrow \mathrm{G} ; \mathrm{L} 392 \mathrm{~V}+$ \\
\hline ALZ 161 & 38 to 42 & 3 & WT & c. $1271 \mathrm{~T} \rightarrow \mathrm{A} ; \mathrm{L} 424 \mathrm{H} \ddagger$ \\
\hline ALZ 191 & 35 to 41 & 3 & c. $2084 \mathrm{C} \rightarrow \mathrm{T} ; \mathrm{T} 714 \mathrm{I}$ & WT \\
\hline ALZ 196 & 50 to 60 & 3 & c. $2092 \mathrm{G} \rightarrow \mathrm{A} ; \mathrm{V} 717 \mathrm{I}$ & WT \\
\hline ALZ 166 & 42 to 56 & 4 & c. $2092 \mathrm{G} \rightarrow \mathrm{A} ; \mathrm{V717 \textrm {I }}$ & WT \\
\hline ALZ 170 & 45 to 57 & 6 & c. $2092 \mathrm{G} \rightarrow \mathrm{A} ; \mathrm{V} 717 \mathrm{I}$ & WT \\
\hline ALZ 221 & 40 to 54 & 3 & c. $2092 \mathrm{G} \rightarrow \mathrm{A} ; \mathrm{V} 717 \mathrm{I}$ & WT \\
\hline
\end{tabular}

When these data are combined with those that we previously published, ${ }^{2}$ and taking into account that the diagnosis of Alzheimer's disease was not confirmed by neuropathological examination in two previously negative families, we conclude that among 65 ADEOAD families, $66 \%$ are attributable to PSENI mutations (62\% if the E318G variation is considered as a non-pathogenic polymorphism) and $16 \%$ to APP mutations, while $18 \%$ remain unexplained. These results, which are in accordance with those published by Janssen et al, ${ }^{13}$ should be helpful for geneticists undertaking molecular diagnosis or genetic counselling for ADEOAD families.

\section{ELECTRONIC DATABASE INFORMATION}

The URL for data presented herein as follows:

Alzheimer Disease Mutations Database: http://www.molgen.ua.ac.be/ADMutations/

Genbank home page: http://www.ncbi.nlm.nih.gov/ Genbank/

\section{Authors' affiliations \\ G Raux, J Bou, D Campion, Inserm U 614, IFRMP, Faculty of Medicine, Rouen, France \\ L Guyant-Maréchal, C Martin, T Frebourg, Department of Genetics, Rouen University Hospital, France \\ C Penet, A Brice, Inserm U 679, Salpêtrière Hospital, Paris, France D Hannequin, Department of Neurology, Roven University Hospital \\ Competing interests: none declared}

Additional data including pedigree structures are available from the corresponding author upon request.

Correspondence to: Dr D Campion, Inserm U614, Faculty of Medicine, IFRMP, 22 Boulevard Gambetta, 76183 Roven, France; dominique. campion@univ-rouen.fr
Received 29 March 2005

Revised version received 28 June 2005

Accepted for publication 2 July 2005

\section{REFERENCES}

1 Sherrington R, Rogaev El, Liang $Y$, Rogaeva EA, Levesque $G$, Ikeda $M$, Chi H, Lin C, Li G, Holman K, et al. Cloning of a gene bearing missense mutations in early-onset familial Alzheimer's disease. Nature 1995;375:754-60.

2 Campion D, Dumanchin C, Hannequin D, Dubois B, Belliard S, Puel M, Thomas-Anterion C, Michon A, Martin C, Charbonnier F, Raux G, Camuzat A, Penet C, Mesnage V, Martinez M, Clerget-Darpoux F, Brice A, Frebourg T. Early-onset autosomal dominant Alzheimer disease: prevalence, genetic heterogeneity, and mutation spectrum. Am J Hum Genet 1999;65:664-70.

3 Arango D, Cruts $M$, Torres O, Backhovens H, Serrano ML, Villareal E, Montanes P, Matallana D, Cano C, Van Broeckhoven C, Jacquier M. Systematic genetic study of Alzheimer disease in Latin America: mutation frequencies of the amyloid beta precursor protein and presenilin genes in Colombia. Am J Med Genet 2001;103:138-43.

4 Lleo A, Blesa R, Queralt R, Ezquerra M, Molinuevo JL, Pena-Casanova J, Rojo A, Oliva R. Frequency of mutations in the presenilin and amyloid precursor protein genes in early-onset Alzheimer disease in Spain. Arch Neurol 2002;59:1759-63.

5 Zekanowski C, Styczynska M, Peplonska B, Gabrielewicz T, Religa D, Ilkowski J, Kijanowska-Haladyna B, Kotapka-Minc S, Mikkelsen S, Pfeffer A Barczak A, Luczywek E, Wasiak B, Chodakowska-Zebrowska M, Gustaw K Laczkowski J, Sobow T, Kuznicki J, Barcikowska M. Mutations in presenilin I, presenilin 2 and amyloid precursor protein genes in patients with early-onset Alzheimer's disease in Poland. Exp Neurol 2003;184:991-6.

6 Campion D, Flaman JM, Brice A, Hannequin D, Dubois B, Martin C, Moreau V, Charbonnier F, Didieriean O, Tardieu S, et al. Mutations of the presenilin I gene in families with early-onset Alzheimer's disease. Hum Mol Genet 1995;4:2373-7.

7 Verkkoniemi A, Somer M, Rinne JO, Myllykangas L, Crook R, Hardy J, Viitanen M, Kalimo H, Haltia M. Variant Alzheimer's disease with spastic paraparesis: Clinical characterization. Neurology 2000;54:1103-8.

8 Zekanowski C, Peplonska B, Styczynska M, Religa D, Pfeffer A, Czyzewski K, Gabryelewicz T, Szybinska A, Kijanowska-Haladyna B, Kotapka-Minc S, Luczywek E, Barczak A, Wasiak B, Chodakowska-Zebrowska M, Przekop I, Kuznicki J, Barcikowska M. The E318G substitution in PSEN1 gene is not connected with Alzheimer's disease in a large Polish cohort. Neurosci Lett 2004;357:167-70. 
9 Aldudo J, Bullido MJ, Frank A Valdivieso F Missense mutation E318G of the presenilin-1 gene appears to be a nonpathogenic polymorphism. Ann Neurol 1998;44:985-6

10 Taddei K, Fisher C, Laws SM, Martins G, Paton A, Clarnette RM, Chung C, Brooks WS, Hallmayer J, Miklossy J, Relkin N, St George-Hyslop PH Gandy SE, Martins RN. Association between presenilin-1 Glu318Gly mutation and familial Alzheimer's disease in the Australian population. Mol Psychiatry 2002;7:776-81.

11 Helisalmi S, Hiltunen M, Mannermaa A, Koivisto AM, Lehtovirta M, Alafuzoff I, Ryynanen M, Soininen H. Is the presenilin-1 E318G missense mutation a risk factor for Alzheimer's disease? Neurosci Lett 2000;278:65-8.

12 Rogaeva EA, Fafel KC, Song YQ, Medeiros H, Sato C, Liang Y, Richard E, Rogaev El, Frommelt $P$, Sadovnick AD, Meschino W, Rockwood K, Boss MA, Mayeux R, St George-Hyslop P. Screening for PS1 mutations in a referral-based series of AD cases: 21 novel mutations. Neurology 2001; 57:621-5.

13 Janssen JC, Beck JA, Campbell TA, Dickinson A, Fox NC, Harvey RJ, Houlden H, Rossor MN, Collinge J. Early onset familial Alzheimer's disease: mutation frequency in 31 families. Neurology 2003;60:235-9. 